\title{
Un-blocking Hedda and Medea through Feminist "Play" with Traditional Staging Forms
}

Ann M. Shanahan

ashanah@luc.edu

Follow this and additional works at: https://ecommons.luc.edu/dfpa

Part of the Fine Arts Commons

\section{Recommended Citation}

Shanahan, AM. "Un-blocking Hedda and Medea through Feminist "Play" with Traditional Staging Forms." Theatre Topics 21(1), 2011.

This Article is brought to you for free and open access by the Faculty Publications and Other Works by Department at Loyola eCommons. It has been accepted for inclusion in Department of Fine \& Performing Arts: Faculty Publications and Other Works by an authorized administrator of Loyola eCommons. For more information, please contact ecommons@luc.edu. (c) $($ ) $(9)$

This work is licensed under a Creative Commons Attribution-Noncommercial-No Derivative Works 3.0 License. (c) Johns Hopkins University Press, 2011. 


\title{
Un-"blocking" Hedda and Medea through Feminist "Play" with Traditional Staging Forms
}

\begin{abstract}
Ann M. Shanahan
Hedda walks to the center of the room clutching to her belly a gun wrapped loosely in red and gold leaves. She sinks to the floor, her black satin dress ballooning around her. Only feet away, the audience can see her expression and interpret her thought process. Hedda looks vaguely around the space for an exit. She responds to Judge Brack (Ibsen 246), her focus less on him than on the gun which she lets rise to her line of vision, trailing leaves as it comes. She raises it slowly to her head and pulls the trigger, then falls gently to the floor. Red leaves fall from her pelvis, stark in contrast against the black of her dress.
\end{abstract}

—Hedda Gabler, act 4, Loyola University Chicago (2006)

As Jason races to the front door for revenge, Medea takes control of a camera filming the event. Her image is projected in large dimension across the house façade. Jason rails and beats the wall, but he cannot touch or hurt her. Defeated, Jason crumples in despair and the action downstage suspends. Medea's image fades and she stands in the doorway of her home clutching two bloody babies to her belly. She walks slowly across her yard, beyond the front gate of the white fence, off the stage and up the aisle of the auditorium. The door of the theatre slams behind her as the chorus chants its final ode, reminding us that the gods do not give us what we expect.

—Medea, final scene, MacAninich Arts Center, College of DuPage (2007)

\section{Introduction}

In 2006-07, I had occasion to direct Ibsen's Hedda Gabler at Loyola University Chicago and Euripides' Medea as a guest artist at the College of DuPage. ${ }^{1}$ Both of these plays revolve around a central female character who is trapped in circumstances that ultimately lead her to kill offspring and depart the scene through death or other-worldly intervention. The women assert creative power through acts of destruction; they mark the physical world as they destroy part of it and then leave it. In an early article on feminist performance theory, "Classic Drag: The Greek Creation of Female Parts," Sue-Ellen Case argues that female characters in ancient Greek theatre, and by extension the Western tradition that it founded, are predicated on the subversion of female creative, sexual, and political authority. The application of Case's argument to considerations of the theatre stage and auditorium allowed me to highlight the conflicts surrounding female creativity through nontraditional treatments of space and reversals in the language of performance at the point of dramatic climax. In short, I explored how applying feminist theories in the physical terms of production can empower female characters whose creativity is limited by the social conventions of the time in which they were written and by the dynamics of the theatrical spaces in which they originally appeared. On one level, I called attention to the masculinist bias inherent both in the texts and in the staging conventions of the originals, and on a second, I manipulated these original spatial conventions to expand the space for the female - in a sense, to make room for her. In what follows, I relate the paths to conceptualization for these productions and describe the characteristics of the staging that resulted. I conclude with 
a look to possible extensions of these physical experiments toward inventing theatrical expressions that can include female creativity without necessitating destruction or departure.

\section{Inspirations from Early Feminist Theory}

I began to think of the theatre space in feminist terms after teaching theatre history using Case's article as a revisionist lens by which to re-view the historical conventions and canonical plays we covered. ${ }^{2}$ Case argues that Greek theatre and thus the Western tradition it engendered are predicated on the exclusion of actual, "real" women, and the creation of a male-represented "Woman." Her arguments for this include reference to a transition in religious structures from Gaia to Zeus; a shift in the god of fertility from Gaia to Dionysus (a male not born of woman, and, importantly, also the god of theatre); ${ }^{3}$ and the elevation of the mannish woman Athena as the presiding goddess of Athens, site of the major theatre festival. Case connects these changes in religion to simultaneous political and social shifts restricting women to the private sphere and, perhaps most importantly, to the performance practice excluding women from the stage and possibly from the audience of the festival as well. Case provocatively suggests that her argument regarding Greek theatre may be extended to all of Western theatre, as its traditional forms, founded on Greek practices and poetics, preserve the absence of real women $(318-25){ }^{4}$

\section{Conceptions of Reproductive Space}

Case's article spurred revisionist reading of canonical texts in terms of gender. As powerful as her arguments are, one is nonetheless struck by how strong women appear with regularity in canonical plays, and how much gender relations reemerge as central themes in the dramas, extending up till the present day. Prompted by consideration of Dionysus as god of both fertility and theatre, one might link the sexual negotiation in theatre to a sexual act, whereby theatre can be seen as a metaphor for the sexual act of creation and be considered an act of "re-production." If actual women were erased at the beginning of the theatrical form, one might argue that the difficulty of creating without female participation in this reproductive art reemerges throughout the form's history in the presence of strong female characters and conflict between the genders. Such references to the female and the resistance to resolution of the conflict generated by her presence demand attention in order to counteract the initial erasure.

As I thought about applying these considerations to production, I conceived of theatrical space in sexual terms. Feminist theorists have developed arguments in sexualized terms for acting methods, dramatic structures, styles, and theories of reception (Austin 77-85); little, however, has been written exclusively on space. In a notable exception, Woman's Theatrical Space, Hannah Scolnikov connects represented space onstage to gender ${ }^{6}$ and traces the evolution of theatrical space to women's relationship to the home and shifting position in society from the time of the Greeks up to the present day. While she does not address the absence of actual women in the reproductive art as Case does, her ideas present a methodology that connects the playing space to elements of female anatomy similar to my production experiments. Starting with the Greeks, theatrical practices can be seen to reflect the cultural ethos, worldview, or system of authority governing the period. The Greek space - an open-air theatre with audience seating surrounding an orchestra - might be read as an open negotiation between a democratic (male) polis, enveloping a focal space of representation and surrounded by wide, unframed nature. Given this pattern and the ways this ethos also include the quotation of "women" as Case argues, how can we see evidence of that in the dynamics of the stage space and auditorium? We can see these as creative (reproductive) spaces, absent of the female, or with the female represented in quotation marks, as Case argued for the creation of female characters. Where, in short, is the phallus, and where is the "womb" and "vagina"? 
Borrowing from critical film theory of the male gaze and identification of the viewer in the phallic, penetrating position, we can look for the equivalent female dynamic in stage space that receives the look. ${ }^{7}$ The central door in the skene presents a potential locale for the vaginal opening. While Scolnikov treats theatrical space (the space of representation on the stage), as opposed to the dynamics of the larger theatre space (stage and auditorium), the development of her argument regarding the sexualization of the skene door is particularly relevant here. Scolnikov's argument regarding the separation of theatrical space into male and female is founded on the implementation of the skene and its iconic division between private and public space, oikos and polis, female and male: ${ }^{8}$ "The dichotomy of the theatrical space brings about its sexualization: as the front of the oikos, the skene wall divides the theatrical space into a male and female space in social and economic as well as sexual terms. The face of the house thus marks the barrier between the genders and it is only on the threshold that man and woman can meet" (13).

As she develops her argument through the evolution of Greek drama, Scolnikov suggests that in Lysistrata, the doors represent "symbolically, the vaginal orifice," as the sex strike is connected to the female occupation of the Parthenon behind the doors. The women barricade the building as a guerrilla action connected to their sex strike and the barricading of their own bodies at their vaginas. As a result, Scolnikov argues, "[t]heatrical space itself is eroticized, every movement within the framework assuming sexual overtones” (38).

These arguments and the thesis of Scolnikov's book in general offer powerful substantiation for ideas of sexualized space in the theatre. They also provide impacting precedent for consideration of the evolution of theatre as a negotiation of power between the genders in terms of space, arguing that the theatre is the channeling of a "primeval strength from the religious into the theatrical sphere" that generates "the explosive confrontation of the genders on scene" (28). Within the context of our argument, and when considered within the larger dynamics of theatre space, the location of the female element at the skene doors links the female, at least visually, with unformed nature, placed in counterpoint to the framed creation of the theatrical - literally outside the realm of representation. Alternatively, if one argues that the skene was literally an enclosed scenic house and dressing room with a rear wall, we may see the female creative locale as a limited and restricting place. Either reading in reference to the skene door limits the scope of female authority within the space and its dynamics.

A second potential location for the female sexual element within the larger space might be the orchestra, implied by its circular shape and original connection to the threshing floor of harvest. ${ }^{9}$ But the orchestra offers no way out as the vaginal opening, hence there was no way out or means of expression into a correlative "real" world for the female in this model. One might argue that the paradoi offer ways in and out of the orchestra, as does the central skene door referenced above. The paradoi provide a complicated, unsatisfactory parallel, however, as there are two of them and they are spatially remote relative to the male identified auditorium, and as they are identified with fictitious locations in the dramatic storytelling outside the dialogue or intercourse with the male audience in the present of performance.

The female womb or creative locale is either excluded from the realm of representation outside in the natural —indeed, set in contrast to the representational space —or is trapped within it with no way out, no means of expression or bodily presence in the real world. The female is either excluded or inscribed. With no equivalent to the vagina, no way to give birth, the female must either kill her offspring within a real or metaphoric theatrical "womb" or leave the terms of representation. The only way the woman can manifest control of her creative potential within the spatial dynamics of the Western theatrical context is to kill or leave. 


\section{The Plays}

In both Medea and Hedda Gabler, female creativity, in physical/sexual and intellectual/artistic terms, is a central subject and theme. In staging the plays, I experimented with the notion that the central conflict regarding creativity was manifest in the spatial storytelling. Both Euripides and Ibsen treat female characters at a crisis of creativity and foreground the women's limited options in the space by strong scenic moves at the point of dramatic climax. Medea is a powerful female character left with no means of controlling her creativity but to kill it. Stripped of her marriage and ordered into exile, she exacts revenge on Jason by taking the only power over him she can-killing their offspring. In his famous use of deus ex machina, Euripides then frees her from conflict with her magical departure in a chariot, raising her outside the arena of the conflict below and outside the reach of retribution. We might argue that this deliberately incongruous staging move highlights the incompatibility of the creative female within the traditional theatrical arena. As Froma Zeitlin writes of Medea, "her spectacular departure from the city on the dragon chariot of her cosmic ancestor, Helios, suggests that there is no place for her in the social structure down here on earth. . . Accordingly it is only logical that she disappear once the drama is over-upward and out of sight" (348). Like the social structure depicted, the stage space cannot contain Medea. The conflict between the genders cannot be resolved there, because it is a reproductive space that does not contain the necessary female part of the reproductive equation.

Like Medea, Hedda's assumption of power within her circumstances involves child killing. Not only does she kill the metaphoric child of her love and her rival in the burning of Lovebourg's manuscript (in a significant symbolic equation between art-making and reproduction), but she also kills her own child when she kills her pregnant self. Like Euripides, Ibsen emphasizes this act spatially by placing it in the inner room at the upstage of the stage space, the regular frame within the proscenium frame in Ibsen's scenic dramaturgy. The scenic space is laid out explicitly in the introductory descriptions, and each component is imbued with a symbolic significance. Ibsen regularly includes an upstage anteroom or window with a frame that mirrors the proscenium frame. ${ }^{10}$ As a result, these spaces take on symbolic meaning with metaphoric implications for the stage space and the style of fourth-wall realism.

Ibsen's placement of Hedda's death in the upstage room that houses the infamous portrait of her father General Gabler accentuates her entrapment. This move not only links her death to her restriction within the house and the world of her father, but also to her entrapment within the theatrical form of framed realism. Ibsen pushes the female subject deep within the symbolic frame of representation, where her lack of an escape route is most viscerally obvious. Rather than call attention to entrapment by incongruously freeing the female subject from the scene of representation, Ibsen emphasizes the restriction of women in the fourth-wall frame by doubling it.

Both playwrights foreground formal elements in a way that calls attention to them. In so doing, Euripides and Ibsen point to the entrapment of the female subjects and the inadequacy of the traditional theatrical space to allow their free expression.

\section{Hedda Gabler}

From the outset of pre-production in 2006, I planned to stage Hedda Gabler in the round in order to scatter the single-sided vantage point of the proscenium orientation and to disrupt the male gaze by providing several surrounding perspectives. This loss of frame supported a second agenda, which was to enhance the symbols and symbolic equations between inner and outer realities. Every element in Ibsen's realistic setting may be considered in symbolic terms; for example, early in the play, lines and scenic notes refer to the time of year and trees in autumn colors: 
TESMAN: What are you looking at, Hedda?

Hedda: Only the leaves. They're so golden. And withered.

TESMAN: Well, we're in September now.

HedDa: Yes. We're already into September. (Ibsen 165)

This classic example of Ibsen's equation of internal and external realities parallels Hedda's sense of aging and compromise with the season and surrounding environment. The team embraced this impulse to symbolism from the outset by bringing the image of the dying though vibrant fall foliage inside the playing space and setting the play in a pile of autumn leaves.

This initial symbolic abstraction in setting was further developed in the production process by the happy interconnection of factors relating to the theories above. My extension of Case's argument to space, and the personal histories of the production team (especially that of scenic designer Timothy Mann, whose wife Mona was pregnant during preproduction), as well as the themes of Ibsen's text itself, led to the development of a central spatial metaphor for the play (Fig. 1). Within the abstraction of the pile of leaves, we had worked to preserve the essential realistic dynamics of Ibsen's prescribed space, including three entrances and three separated areas within the drawing room. This led to a space of triangular patterns. When I first saw the ground plan-an aerial view of the design-I was reminded of a frontal view of a female reproductive system, such as one sees in a doctor's office figure or model, including a uterus center flanked triangularly by fallopian tubes and vagina. Reading the ground plan as this suggestive symbol, I arrived at a metaphor that was to stay with us throughout the staging process: the space was a womb filled with autumn leaves.

I set the audience within the same space as the actors, situating them inside the site of creation-inside the frame, inside the womb-rather than viewing or entering it from the outside. Students playfully adopted a shorthand for locales on the ground plan, labeling the vom entrances as "fallopian tubes number one and two" and the downstage entrance as the "vag." The association of the stage and auditorium space with a uterus was never made explicit to the audience in any way; the only suggestion would have come from subliminal awareness of the revision of the traditional proscenium orientation of the play in its original context, as well as from the themes of the play that refer to creative acts as making a child, and thus the creative space (here, the theatre) as the space in which a child of sorts (here, the play) was made.

However, importantly, the cast was aware of the significance, which contributed to a series of staging choices reinforcing the central metaphor. These graphic identifications in female anatomy led to interesting revelations about Ibsen's conscious or unconscious symbolic use of space. Staging with these terms, we noticed that the female characters Auntie Juju and Berta, both interested in Hedda's good health and pregnancy, consistently move back and forth up and down the "tubes," and, significantly, the only character to enter the "vag" (the door to the garden in our rendering) is Judge Brack. The only other time that entrance is used is when Hedda points the gun out of the opening, in a significant gender reversal of phallic orientation and power (Fig. 2).

We ultimately extended the framelessness of style both in the arena seating and in the connection between the inner and outer realities by telling the story in increasingly symbolic terms. Likewise, the limits of the small playing space necessitated eliminating some elements of Ibsen's scenic description. Extending our symbolic abstractions, we eliminated the stove and refigured the burning of the manuscript. On many levels, Ibsen had already created a symbol and visual metaphor around the burning. The visual dramaturgy of the play can be considered a burning: a heightening in the intensity of the fall's fire colors, to Hedda's act of burning the manuscript, and then the final act in the ashes of mourning. Without a stove, Hedda's act of destroying the manuscript - "burning it," became a scattering, like the scattering of the single-sided audience vantage point of traditional realism. The evidence of the scattering was then left present in the final act as the "ashes," white against the scattered leaves. Leaves and paper became one, refuse of a natural cycle of dying and killed creativity. 


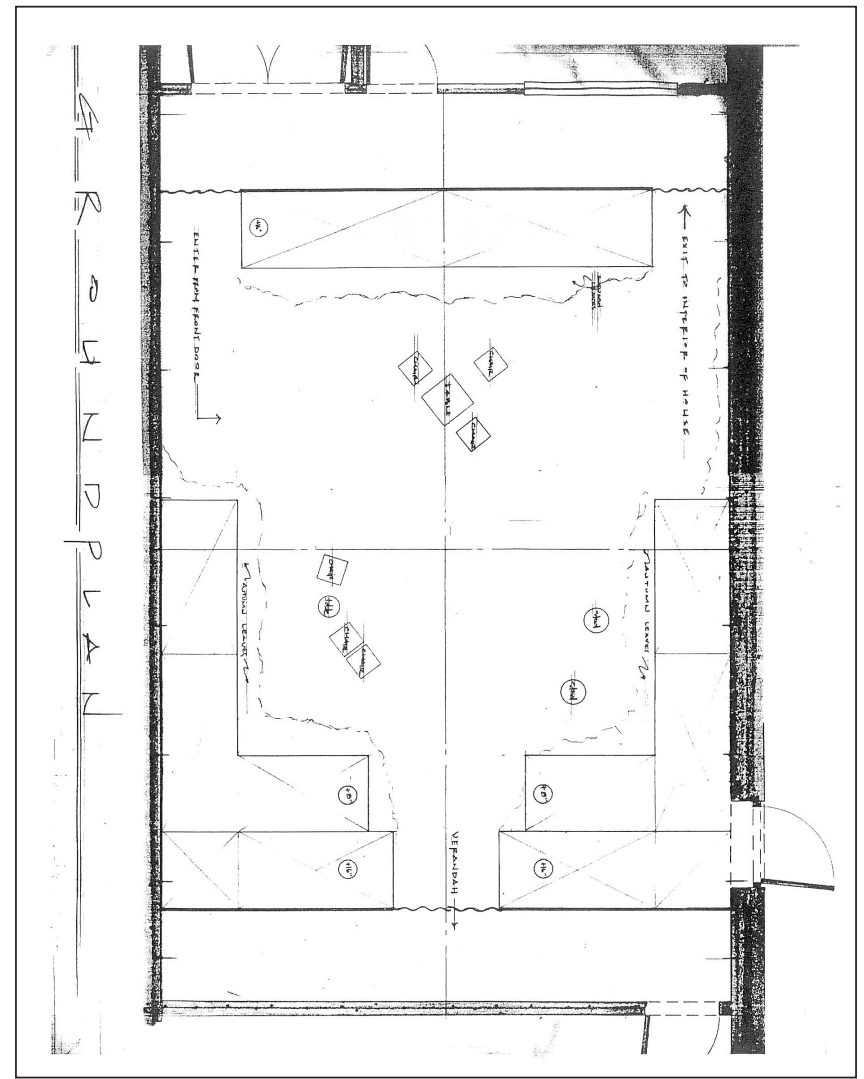

FIG. 1. Hedda Gabler ground plan. Scenic design by Timothy Mann. (Photo: courtesy of Timothy Mann.)

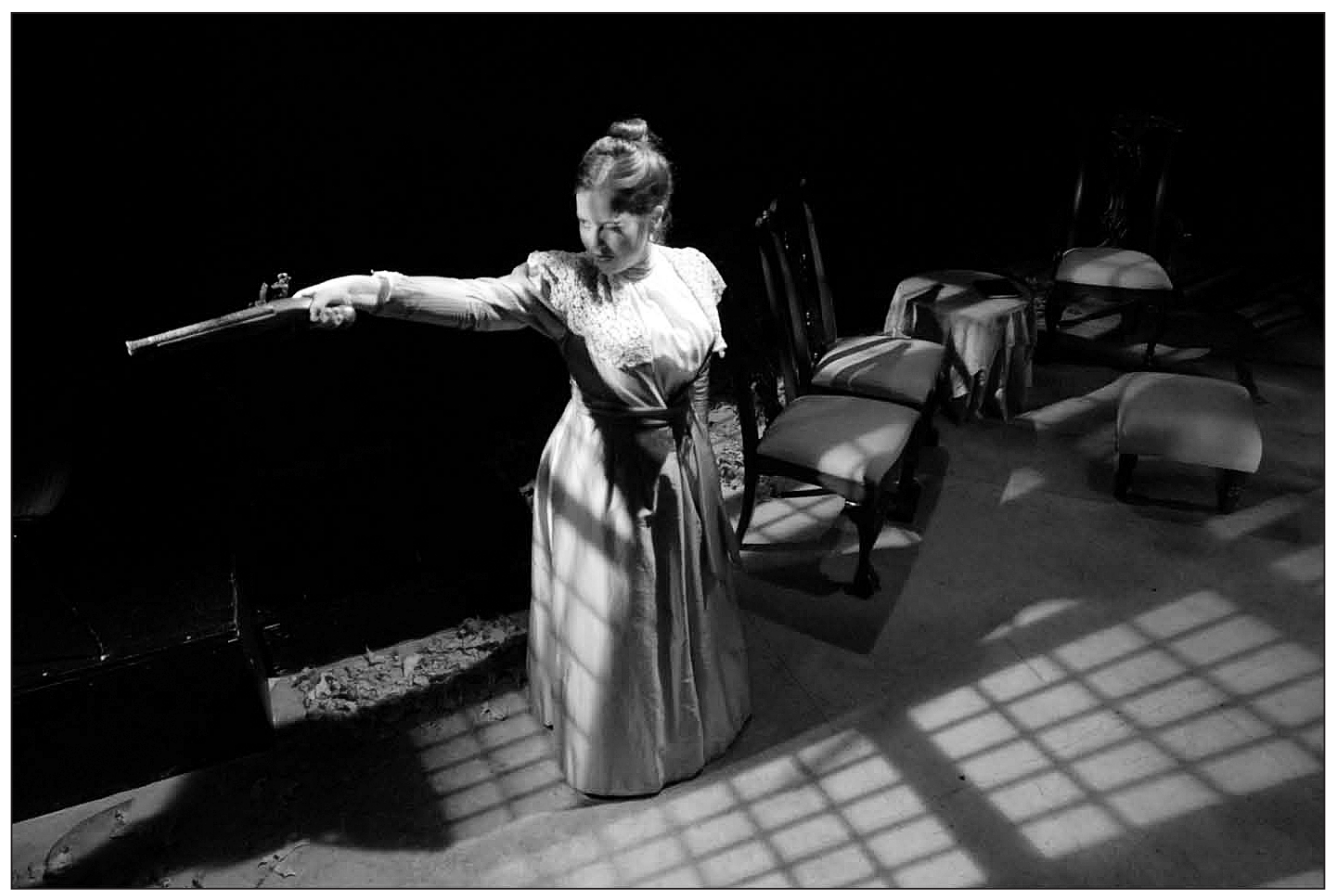

FIG. 2. The beginning of the second act of Hedda Gabler. (Photo: John Flack, courtesy of Loyola University Chicago.) 
By necessity of space and unconscious theoretical impulse, we also got rid of the inner room and its frame. Absent this, we considered where to stage Hedda's death. We concurred that Hedda would die center, unhidden by a door or curtain, as she was unframed. The center seemed the equivalent locale to the upstage space, as it was the most distant point from every audience member and corresponds to upstage center in the arena configuration. This place for her death was potent in implication. It had the result of heightening our response to her entrapment, as we saw every moment of her decision to kill herself. The entrapment was kinetically reinforced by a progressive obstruction of each of the entrances, tubes, and vaginal opening with furniture and debris, as Brack closes in on Hedda in the final scene. We extended Hedda's preoccupation with rearranging furniture in her moments alone so that by the end each of the entrances was blocked by furniture. We also brought Thea and Tesman to the floor as they piece together "notes" of the manuscript; each brought a lamp down and collected the papers, encircling the room and adding to Hedda's enclosure and entrapment center.

Hedda dies then in the most remote, enclosed place-within the womb, unexpressed, un-freed. This image was accentuated by a rich instinctual choice on the part of the actress playing Hedda (Bethy Poluikis) to hide the gun in a pile of leaves and then to gather some as she retrieved it on her way to center stage. When the gun fell from her hand, red autumn leaves lay at her pelvis - blood from the murder and from her womb (Fig. 3). This center-stage killing highlighted the lack of frame, being not hidden offstage as in the original or its Greek antecedent ${ }^{11}$ but instead visible, without a barrier. The female creative act, albeit death, occurred inside the space shared by performer and audience, evoking a sense of implosion in the space mirroring the contradictory act of taking power by dying.

This conception of the space as a blocked or quoted womb contributed to a series of staging choices made by me and the actors and designers, which combined to create a kinetic counterpoint to the staging of the climactic scene in traditional terms. The effect was one of closeness, and even of anti-climax in the lack of surprise. None of the specific metaphors was made explicit to the audience, but the shared space and proximity allowed them to participate in Hedda's experience, rather than to observe it with judgment from the outside. With distance from the storytelling methods of the original, the audience experienced increased access to the female protagonist.

The choice to set the event metaphorically within the female body corresponds to likewise early feminist theorizing on the means of establishing female subjects onstage and feminine points of view to dramatic storytelling. As Helene Cixous writes: "By writing her self, woman will return to the body which has been more than confiscated from her, which has been turned into the uncanny stranger on display. ... Censor the body and you censor breath and speech at the same time. Write yourself. Your body must be heard" (880). This experience was available to me as director on this production. Situating the play in the female anatomy was a way of "writing" as a director from my body. I was quite literally able to use "my gut" as a guide and inspiration to blocking and staging choices in a more concrete way than ever before. Rather than make choices on a purely visual, pictorial level, I empathized with Hedda's spatial circumstances kinetically, quite literally feeling my way to staging by how sensations resonated in my pelvis.

The resulting storytelling likewise corresponds to a dramaturgical principle dubbed "contiguity" by contemporaries of Case and Cixous. As Case explains: "This is an organizational device that feminists have discovered in both early and modern works by women. Luce Irigaray describes it as a 'nearness,' creating a form constantly in the process of weaving itself . . concerned not with clarity, but with what is touched upon. Cixous calls it working 'in the between' and Jane Gallop describes it as a register of touching, nearness, presence, intimacy, contact" (qtd. in Feminism and Theatre 129). Although I did not aim at the outset to evoke or utilize the above theories of feminine morphology in staging Hedda, the stylistic characteristics described by Cixous and others were generated as a 


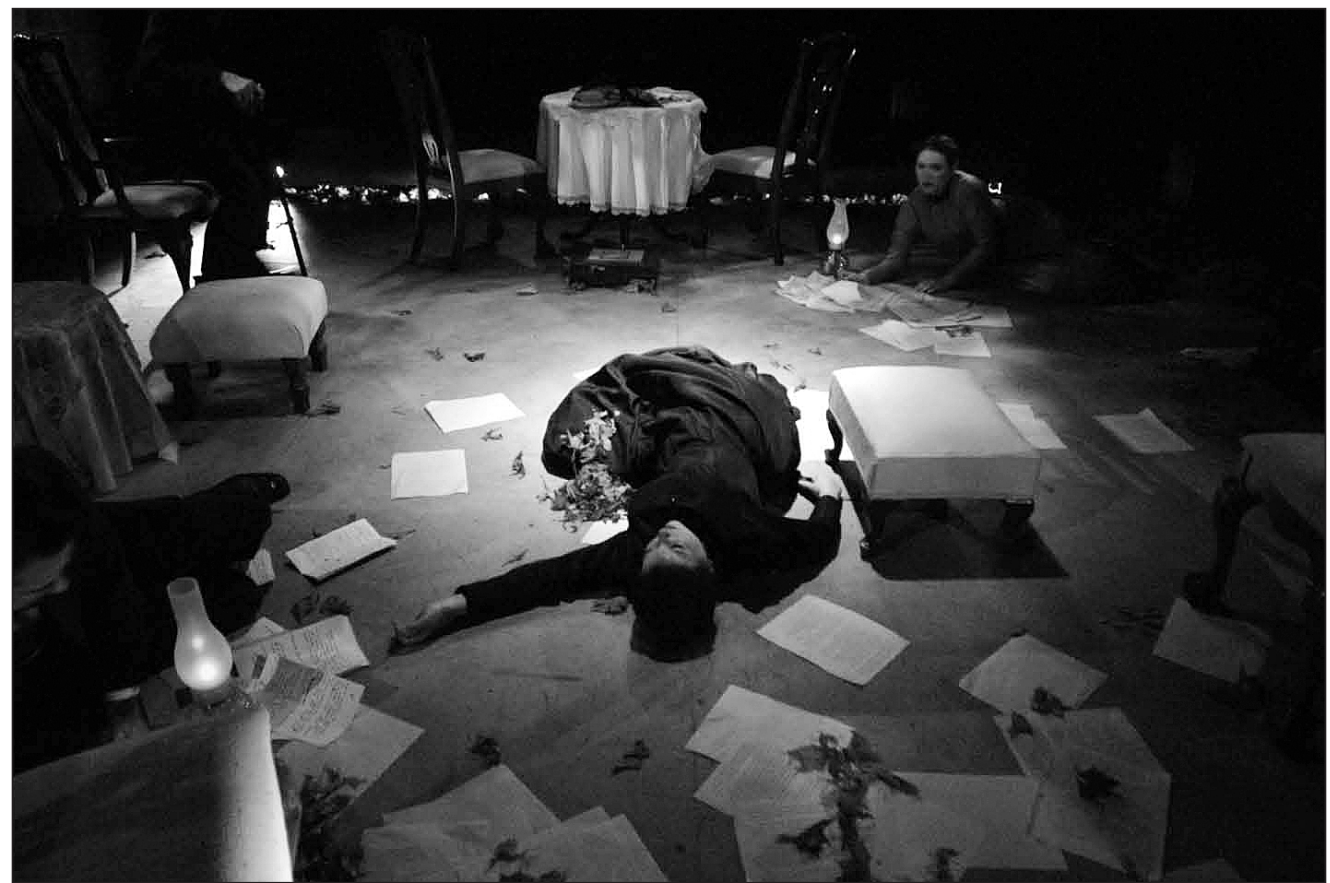

FIG. 3. The end of the fourth act of Hedda Gabler. (Photo: Chris Ocken, courtesy of Loyola University Chicago.)

natural extension of considering the space in the sexualized terms outlined earlier. Playing within this framework of sexualized theatre space led to results that correspond to other strategies advocated by early feminist critics to create space for a female subject onstage.

\section{Medea}

My initial thoughts about Medea—staged six months later-were more socially oriented, although I was similarly mindful of reproduction and representation in theatrical space. I sought a context for the play that would accentuate the relevance of its story and the ancient theatrical form. I was directing in the relatively affluent western suburbs of Chicago and wanted to relate the play specifically to that locale. I considered television our contemporary cultural equivalent to the City Dionysia of the fifth-century BCE and noted the contextual similarities in the television program Desperate Housewives with the circumstances of Medea. The group of female neighbors worked as the chorus of women. I arrived at a setting in an imaginary western suburb called Corinth, Illinois. The theatre at the College of DuPage is a thrust-like stage with audience three-quarter surround like a Greek theatre. Exterior images of the house fronts on Wisteria Lane worked as skene to an orchestra lawn bordered by a picket fence (Fig. 4). ${ }^{12}$

While the application of my extensions of Case's argument to reproductive space were less literally applied in this reading, I nonetheless conceived of the stage space as a male-quoted womb in relation to a phallic-oriented theatron of viewers. In this reading, I connected Medea's removal in the chariot in the original to the notion that she could not be contained within this original context. I sought to find an equivalent to the deus ex machina that would remove Medea incongruously from a sexual space that does not, and cannot, contain the female. The search for this equivalent was a central question in modernizing the locale. Given the many parallels in the current translation of the myth, we nonetheless faced significant interpretive questions. One such was a system of rule equivalent to the power of King Creon, who could banish Medea. We then needed the "god from 


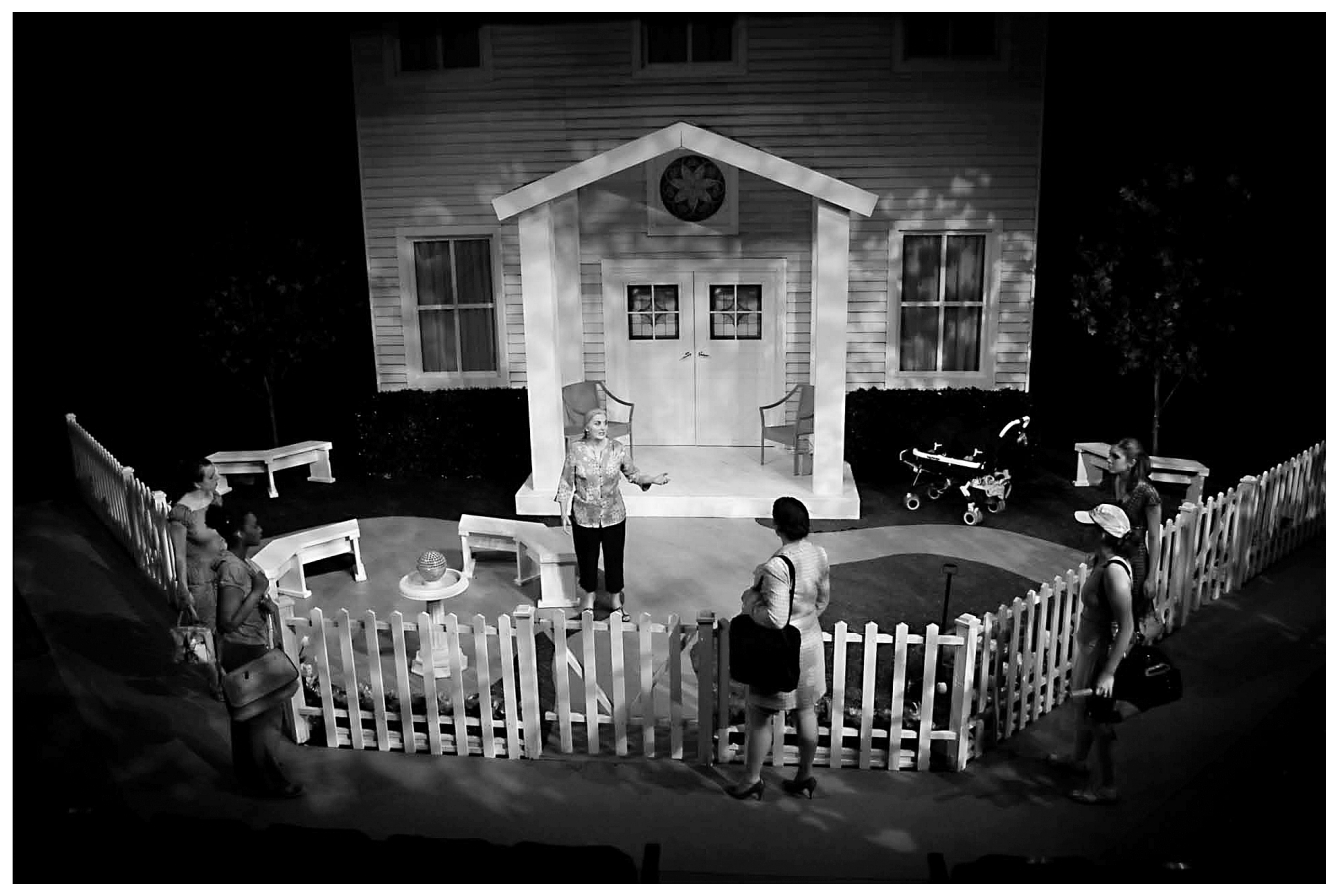

FIg. 4. Medea Parados: Nurse and Chorus. (Photo: Donald Hood, courtesy of College of DuPage.)

the machine" in relation to this contemporary context of authority, one that that would remove Medea from the established conventions of representation, as in Euripides' original.

Ultimately, the system of rule and the deus ex machina became linked. Creon was a small-time politician followed by an entourage of media. For the deus ex machina, we arrived at a two-part moment, playing on the context of representation in a televised world. The camera crew, which has been covering the unfolding story, was present when Jason learned of the murder of his children and then stormed the doors of the house where Medea was hiding. At this point in the original, Medea appears in a chariot above the house/skene for a brief exchange, implying that she will escape on this chariot. In our version, Medea's face was projected in large dimension over the surface of the house façade. In shock, the newsmen struggled to understand how they had lost control of the camera. Medea (the actress recorded live offstage) engaged in dialogue with Jason, but he could not reach, touch, or hurt her image, which was digital and outside the material terms onstage (Fig. 5). By this act, Medea takes over the means of production, means of representation, thus assuming the male gaze in physical terms. ${ }^{13}$

As striking as the projection was, however, I did not feel that the final action was complete in this moment. I did not want to leave Medea trapped outside of, and literally larger than, the material terms of life. The second part of the moment had Medea walking out of theatre into reality and unframed life. As a materialist feminist with a Brechtian background, I wanted to locate Medea's body in the real time of the theatre and the world of the audience; I wanted her to walk out of the representative frame into the real world. At the end of her dialogue with Jason, the image of her face on the house front faded, and the rest of the action froze as the actress walked out of the house, across the lawn, past Jason and the chorus, out of the picket fence's gate, up the aisle of the auditorium, and out with a bang of the theatre door, reminiscent of Nora's. In Medea, by traversing the auditorium space, the female subject had forged a means of egress - the way out missing from the sexual model generated from traditional Greek theatre. Breaking the wall and traversing the audience's territory, the female subject shared space with the viewer, similar to the space of Hedda's suicide. Extending 


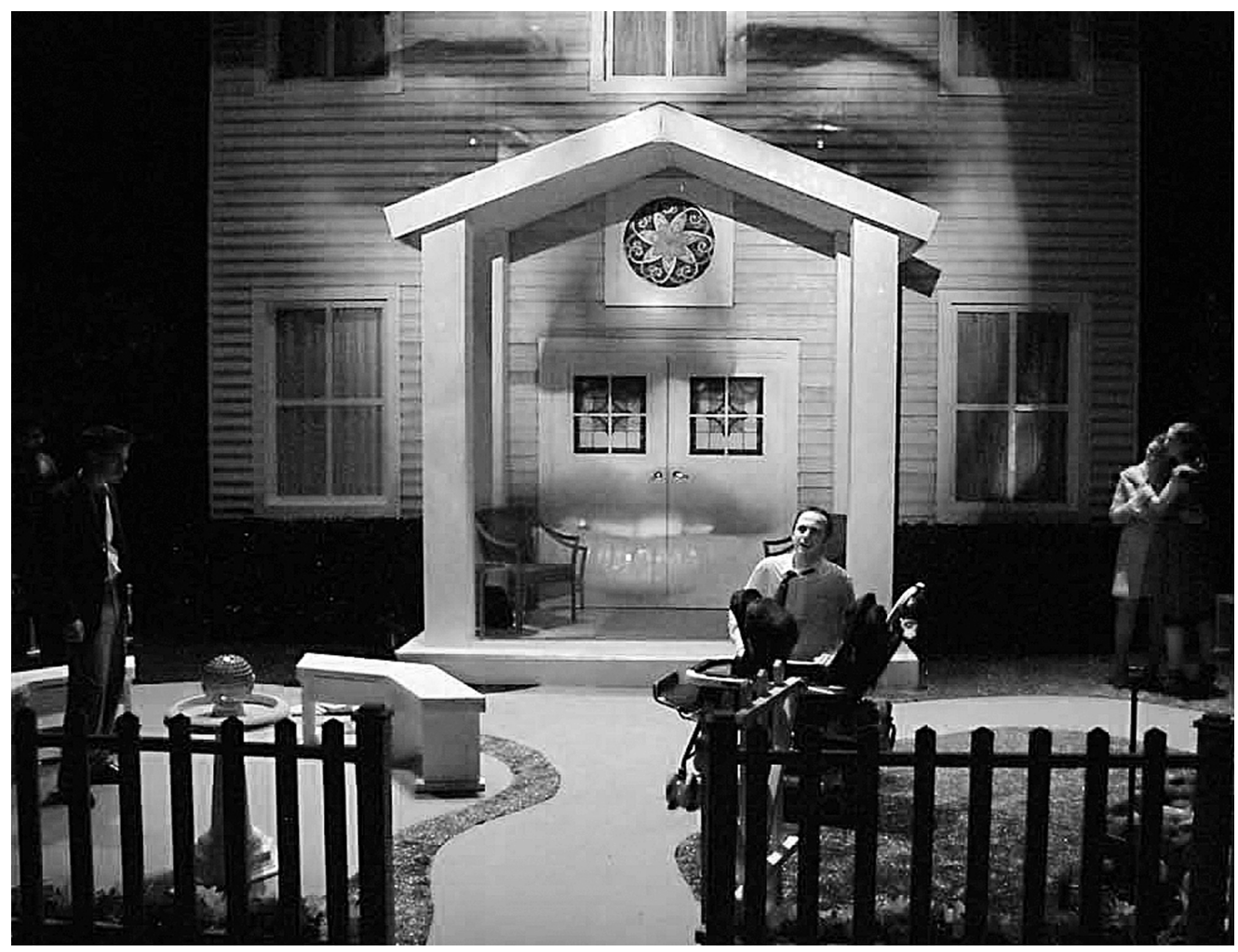

FIG. 5. Medea: "Medea is seen in a chariot, in the air." (Photo: Donald Hood, courtesy of College of DuPage.)

Case's arguments to space suggest that a lack of frame and boundary around the female subject is a natural means to break the objectification inherent in a frame and in realism as a style. As a female director, I exercised "control" of the theatrical image, just as Medea had assumed control of the camera's projection moments before. This deliberately juxtaposed the control of representation, having the effect of distancing the audience from norms and of emphasizing the malleability of the interpretive point of view.

By demonstrating alternative forms of presence, in comparing material and immaterial representations, and in consideration of the control of "means of production," I engaged with material feminist theories and referred to my own background in Brechtian theory. While these schools are in historical tension with the feminism traditionally attached to the resolutely anatomical theories founding these staging experiments (and connected to theorists Cixous and others mentioned above), this marriage of theories itself bears interesting fruit. First, this simultaneous application of conflicting theories embodies Case's suggestion that we ignore theoretical tensions in favor of political efficacy. In Feminism and Theatre, Case negotiates the tension of conflicting theories in practice: "It seems, however, that certain gains can be realized from both sides of the issue. Perhaps these positions could be combined in some way. . . . The feminist activist-theorist can employ any techniques, methods, theories or ways of social organizing she wishes in confronting or creating the situations in which she operates" (130-31). Additionally, while the cultural and material feminisms are at some odds with one another theoretically, in practical application both suggest similar methods of representation: both suggest breaking frames, as well as proximity to, and shared space with, the audience. In the physical terms of production, techniques associated with Brecht's Epic Theatre and its Marxist materialism—broken fourth walls and direct address—-manifest from consideration of the stage space in anatomical terms. 


\section{Conclusions}

One might argue that both Euripides and Ibsen manipulate the staging conventions of their respective periods in creating resolutions that call attention to the formal composition of the traditionally rendered space. Reading these plays as gender-based negotiations of space-thus reading their resolutions in gendered terms-presents unique means of accommodating a female subject within the texts of the dramas and the physical environs of the theatre. In my production of Hedda Gabler, this was accomplished by shifting the single-sided proscenium dynamics that support the male gaze, thus inviting the audience into the space of representation. By including the audience in the creative space of representation, we could amplify the symbolism already present in Ibsen's realism and develop abstractions that elevated the emotional arcs of the play. This move also involved the audience in the actual act of art-making in order to empower the viewer and suggest collusion in the represented acts. Without the distance that engenders objectification and judgment, the audience participates in the process of meaning-making with the creative female. While nonetheless the subject ultimately dies, and is not freed even in this model, audience members are made aware, if only on a visceral level, of the entrapment inherent in the realistic representational forms, because they experience it kinetically with the character.

In Medea, the space created for a female subject was forged again by a reversal in traditional forms that both called attention to the gender bias inherent in those forms and suggested means of breaking the biases by feminist control of space. This included overt manipulation by the female subject of the means of "re"-production-both in Medea's assumption of the camera lens and the implied female power to control the suspended action onstage when she walked retribution-free through the picket fence-lined orchestra, up and out of the auditorium. By this act, walking out of the framed worlds of both the stage and filmed spaces and up the aisle to the exit, she forged a means of expression and escape, the vaginal passage missing from the sexualized model of the ancient Greek auditorium.

By playing with feminist theories of space in production, a feminist theatre practitioner may experiment with means of reversing the gender biases inherent in classic Western plays and their traditional methods of production. In my productions of Hedda and Medea, the most dominant quality fueling both very different experiments was a sense of thrill, of risk-taking that was near irreverence. To have those risks met and meaningfully accepted by layers of receivers-designers, actors, and, finally, audiences - was happily empowering. It is my hope that these methods suggest unique alternatives to other feminist strategies in allowing for female subjects and productive female creativity onstage.

\section{Acknowledgments}

Gratitude to the production staffs at Loyola and College of Du Page for their inspiration and willing spirits; thanks to Elizabeth Hemenway, Peter Kanelos, Verna Foster, and Pamela Hendrick, Rebecca Daniels, and Mary Ann Shanahan for reading earlier drafts of this article. Thanks to the readers and editors of Theatre Topics for detailed suggestions, and, finally, profound thanks to the casts of both productions.

Ann M. Shanahan is an assistant professor of theatre at Loyola University Chicago, teaching acting, directing, and analysis courses. She holds a B.A. in drama from the University of Michigan and an M.F.A. in directing from Northwestern University and has directed professional productions for Chicago's City Lit Theatre, Buffalo Theatre Ensemble, the Brecht Company, and the Drama League Director's Project in New York. In 2009, she was awarded a fellowship from the Gannon Center 
for Women and Leadership for her research project, titled A Room of One's Own: Women, Creative Leadership, and Home, which explores the role of home and houses in women's creative lives. Her articles have been published in Theatre Journal, Text and Presentation, and Theatre Topics, and she has presented numerous papers on acting and directing pedagogy at the Association for Theatre in Higher Education and Comparative Drama conferences. Shanahan is a recipient of the Drama League of New York Directing Fellowship. She is currently writing a book on Chicago theatre directors.

\section{Notes}

1. The production team for Medea was: scenery, Galen Ramsey; lighting, John Gantt; costumes, Joanne Witzkowski; and sound and technical direction, Michael Moon. And the team for Hedda Gabler: scenery, Timothy Mann; lighting, Ryan Williams; and costumes, Jacqueline Firkins.

2. I gratefully inherited this unit from Dr. Susan Applebaum.

3. Thanks to the anonymous reader who pointed out that there are other female gods associated with fertilityDemeter, for example.

4. While Case's argument does not acknowledge the considerable variations in Western theatre and cross-cultural influences that have led to shifting forms and orientations, her strong arguments inspire thought, at the very least in reference to canonical plays with direct reference to classical poetics and practice.

5. Indeed, of the plays covered in this inquiry, symbolic allusions in Hedda Gabler exemplify a regular equation of art- and child-making, through the repeated references to artistic and intellectual expression as a "child" created by Eilert and Thea. Likewise, references to Dionysus and beauty-making, or artful creativity, rise throughout the play in Hedda's desire to see Eilert with "vine leaves in his hair" (Ibsen).

6. Zeitlin makes equations of space and gender as well, although her arguments are limited to Greek theatre and are not explicitly anatomical, as are Skonikov's.

7. Descriptions of the "male gaze" in reference to theatre criticism, as well as an overview of feminist critique of dramatic structures and acting theories may be found in the closing chapter of Case's Feminism and Theatre.

8. While in some classical Greek plays the skene separates oikos/polis and female/male spaces less explicitly than others, Skolikov and Zeitlin connect their arguments to larger socioeconomic trends in relation to domestic and public space in Greek culture. Thanks to the anonymous reader and Gregory Dobrov and Jacqueline Long, scholars in classics at Loyola University Chicago, for assisting in clarification of this point.

9. Scholars link the origins of the ancient Greek orchestra to a threshing floor, although the original circular shape is debated based on lately discovered ruins suggesting an early rectangular floor. These arguments are summarized in Edwin Wilson and Alvin Goldfarb's chapter on "Greek Theatre" in The Living Theatre, with an accompanying bibliography for further reference.

10. Examples of upstage center spaces in Ibsen's scenography include the picture window in The Master Builder, the entrance to the conservatory in Ghosts, and the large window in The Wild Duck.

11. Most violence, killings, and maiming in Greek tragedy occurred offstage. An anonymous reader pointed out the possibly notable exception of the suicide of Ajax in Sophocles.

12. While certain conceptual points were realized in this transposition, other stylistic equations did not transfer. By placing the play in a setting that referenced a familiar televised reality, we connected the form of the drama 
to the dominant form of popular entertainment. But the difference in style between the poetic tragedy and the melodrama/farce of Desperate Housewives did not connect as successfully. Ultimately, this discrepancy in style was remedied by making the setting less specifically refer to the television show, and for it to more generically evoke an affluent American suburb.

13. The feminist implication of digital representation of Medea has been explored by Susan Kozel in her "MultiMedea: Feminist Performance Using Multimedia Technologies."

\section{Works Cited}

Aristophanes. Lysistrata. Trans. Dudley Fitts. The Bedford Introduction to Drama. 5th ed. Ed. Lee A. Jacobus. Boston: Bedford/St. Martin's P, 2005.

Austin, Gayle. Feminist Theories for Dramatic Criticism. Ann Arbor: U of Michigan P, 1990.

Case, Sue-Ellen, "Classic Drag: The Greek Creation of Female Parts." Theatre Journal 37.3 (1985): 317-27. Feminism and Theatre. New York: Routledge, 1988.

Cixous, Helene. "The Laugh of the Medusa." Trans. Keith Cohen and Paula Cohen. Signs 1 (1976): 875-93.

Euripides. Medea. Trans. Nicholas Rudall. Chicago: Ivan R. Dee, 2000.

Ibsen, Henrick. Hedda Gabler. Trans. Michael Meyer. The Wild Duck and Hedda Gabler. New York: W. W. Norton, 1997.

Kozel, Susan. "Multi-Medea: Feminist Performance using Multimedia Technologies." The Routledge Reader in Gender and Performance. Ed. Lizbeth Goodman and Jane de Gay. London: Routledge, 1998.

Scolnikov, Hannah. Woman's Theatrical Space. Cambridge: Cambridge UP, 1994.

Wilson, Edwin, and Alvin Goldfarb. The Living Theatre. 4th ed. New York: McGraw-Hill, 2003.

Zeitlin, Froma. Playing the Other: Gender and Society in Classical Greek Literature, Chicago: U of Chicago P, 1996. 